\title{
Education for information in Portugal: Evolution, institutional context and some reflections
}

\author{
Fernanda Ribeiro* and Olívia Pestana \\ Department of Communication and Information Sciences, Faculty of Arts and Humanities, University of \\ Porto, 4150-564 Porto, Portugal
}

This article starts by a brief overview of the evolution of education in Information Science in Portugal. After, there is a description of the paradigm shift and the significant changes caused by the impact of social, economic, cultural and technological conditions of the information era as well as the emergence of Information Science as an academic field and a new education model in accordance to it.

The current situation of IS in the academic context is analysed and some final reflections are exposed in a prospective view towards the next future.

Keywords: IS education in Portugal, IS education model, Portuguese IS programmes

\section{The evolution of Information Science (IS) education in Portugal (1887-2001)}

The Portuguese reality in what concerns Information Science (IS) ${ }^{1}$ education reflects a large evolution ${ }^{2}$ that goes back to 1887 and can be characterized in some distinctive aspects:

- Portugal is one of the countries in the world where libraries and archives education at higher and academic level began earlier;

- from the beginning, the education of librarians and archivists was delivered in an integrated way (in the same programme);

- the participation of professional associations in the education process started later than in other countries, in the 80 's of the $20^{\text {th }}$ century;

- the academic education at undergraduate level (bachelor) only began in 2001.

\subsection{The earliest training programme: The Higher Programme for Librarians and Archivists (1887-1982)}

The first and innovative programme of professional education, of higher level,

* Corresponding author: Fernanda Ribeiro, Department of Communication and Information Sciences, Faculty of Arts and Humanities, University of Porto, Via Panorâmica, s/n, 4150-564 Porto, Portugal. Tel.: +351 226077100; Fax: +351 226091610; E-mail: fribeiro@letras.up.pt.

${ }^{1}$ We use the term 'Information Science' to name the scientific field that is currently accepted and under this term we include several training programmes and courses related to information. Of course, in the past, the education programmes had other designations, more related to archival science, library science or documentation.

${ }^{2}$ For a further approach of this evolution, see: Ribeiro (2008). 
devoted to train librarians and archivists, was created in 1887 with the name of Curso Superior de Bibliotecário-Arquivista (Higher Programme for Librarians and Archivists). It included general subjects, such as Portuguese and Universal History, Philology, Latin and Greek Literature, Modern Literature of Europe, which were taught in the Curso Superior de Letras (Higher Programme in Arts and Humanities) in Lisbon, and specialized subjects (Diplomatics, Numismatics and Bibliology), that were taught in the National Archives (Torre do Tombo) and in the National Library by professionals of these institutions.

After the establishment of the Republic in 1910, the State interest in the promotion of culture and public instruction increased and, consequently, the concerns about access to information, public reading, promotion of libraries and archives heightened. In 1911 the University of Lisbon was established and the Curso Superior de Letras was transferred to it. Therefore, the archivists and librarians' education became integrated in the academic space, but the specific subjects remained taught at the National Archives and at the National Library.

In 1931, major changes occurred. The Higher Programme for Librarians and Archivists was reformulated in order to be an "exclusively professional" programme; it was taken out of the university and its tutelage became the responsibility of the Inspectorate of Libraries and Archives. The admission conditions also changed and the programme was transformed into a postgraduate one, which required a prior degree in the Humanities or, at least, education in some humanistic subjects. The technical aspects were strengthened and those related to general and cultural subjects were reduced. However, after some years, it was recognized that it was difficult to maintain this programme, disconnected as it was from an academic institution, and managed by the technical services that were responsible for the teaching.

Therefore, in 1935, a new reform led to the Higher Programme for Librarians and Archivists being restored and established in the Faculty of Arts and Humanities of the University of Coimbra. It remained a two year postgraduate programme, with a practicum of six months, and any graduate who passed an entry examination in general culture could be admitted into it. The Higher Programme for Librarians and Archivists included Palaeography and Diplomatics, Numismatics and Sphragistics, Bibliography and Librarianship in the first year and, in the second year, an advanced course in Palaeography, Archivology and Archivoeconomy.

For nearly a century (1887-1982), the Higher Programme for Librarians and Archivists was the only way to train information professionals in Portugal. This programme followed a historicist and erudite matrix based in the French model, established at the École des Chartes in the $19^{\text {th }}$ century, but the professionals felt the necessity of a new education model with more emphasis in technical and technological issues. This feeling led to the discontinuation of the Higher Programme for Librarians and Archivists in 1982 and its replacement by a new education model named Curso de Especialização em Ciências Documentais - CECD (Specialization Programme in Documentation Sciences). 


\subsection{A new education model in 1982: The Curso de Especialização em Ciências Documentais - CECD (Specialization Programme in Documentation Sciences)}

The CECD brought not only a significant change in the curriculum but also a structural change - it introduced for the first time the separation of archivists' training from librarians/documentalists' training. It was a two years postgraduate programme, with a common set of courses in the first year and a division in two branches ('archives' and 'libraries/documentation') during the second year. This happened not because of scientific or theoretical reasons, but as a response to professional activities and corporate interests. In spite of the word "specialization" in its designation, this programme was in fact, an initial training because it did not require a previous qualification in the field of librarianship or archivistics.

The expectations of a curriculum oriented to enlarge the capacity for using information systems and networks and to develop documentation services, libraries and archives were not really achieved with the new education model established in 1982 and soon after its beginning, it became the object of many criticisms. However, despite those criticisms, the CECD became the "official" training model in Portugal and in accordance to the law, the only one recognized for employment as a librarian, an archivist or a documentalist in the public administration services.

The CECD programme began to be taught one year later in the Universities of Coimbra and Lisbon and three years afterwards, in 1985 in the University of Porto. In 1988, a private university also obtained permission to teach this programme. Until the end of the century, Portugal had this type of education in four universities and trained about 120 information professionals per year.

After 2000, and considering the crisis of universities in the Humanities, the growth of the CECD programme has been remarkable and it was established in several public and private universities. In 2007, there were 17 programmes offering it and it is possible to estimate that the admission to these programmes grew to about six hundred students per year at that time. ${ }^{3}$

Aside from some gaps in the CECD curriculum, three other main problems in IS education appeared: the lack of a progressive education model (from bachelor to $\mathrm{PhD}$ ) within the University; the lack of teaching staff exclusively devoted to an academic career; and the prevalence of practice over academic and scientific concerns. In fact, only the universities of Coimbra and Porto admitted full-time teachers in the CECD; in the other universities, either public or private, the teaching was done by professionals (librarians, archivists, historians, computer people or managers) who taught at the university part-time and did not have the conditions nor the motivation to devote themselves to research.

By positioning themselves differently and undoubtedly in line with IS new trends, some institutions partnered with foreign universities to create master's programmes.

${ }^{3}$ About the training offered in Portugal in the last 3 decades, see: Pinto (2008). 
Such was the case of the Master of Science in Information Management programme created in the beginning of the 90's by the University of Sheffield (with the support of professor Tom Wilson), established in partnership with the LNETI (National Laboratory of Engineering and Industrial Technology). The Faculty of Engineering of University of Porto started a Master in Information Management in 1997.

Doctoral studies began in 1989 in the Faculty of Arts and Humanities of University of Porto. A doctoral programme was also established at the University of Coimbra in 1996. However, the lack of faculties offering a PhD in Portugal forced the small number of $\mathrm{PhD}$ students to look for academic supervision abroad, mainly in the United Kingdom.

\section{The new curriculum in Information Science (2001) and the changes with the "Bologna Process"}

In face of the weaknesses of the dominant educational model (CECD) - i.e., a clear orientation towards professional practices and the absence of scientific grounding -, a new model was designed under the name of Information Science which corresponded to an effective paradigm shift. This new perspective, developed at the University of Porto, was based on a new scientific-informational paradigm that emerged in the last decade of the $20^{\text {th }}$ century. It integrated Archivistics, Librarianship, Documentation and Museology as applied areas in the field of Information Science. It has been the object of a deep reflection at epistemological and theoretical levels, which led to the edition of a book entitled Das "Ciências" Documentais à Ciência da Informação: ensaio epistemológico para um novo modelo curricular ${ }^{4}$ (Silva \& Ribeiro, 2002).

Briefly, it must be stated that 'the information' which is understood as the object of Information Science is, naturally, social information (distinct from genetic or biological information and physical or thermodynamic information), thus understood and defined as a set of mental, coded and socially contextualised representations (significant symbols) capable of being recorded on any medium (paper, film, magnetic tape, etc.) and, therefore, permanently communicated. Furthermore, the fact that information has a psycho-social character and that its mental origin makes it an entity in itself and gives it an existence prior to its materialisation (record).

In this new perspective, the adoption of systems theory ${ }^{5}$ as a reference and an interpretative tool for any scientific study, whether theoretical or practical, is another element that characterizes the scientific turn towards Information Science. And the adoption of a methodological approach, based in Paul de Bruyne and other authors'

\footnotetext{
${ }^{4}$ Title translation: From Documentary Sciences to Information Science: epistemological essay for a new curriculum model.

${ }^{5}$ About the systems theory and thinking it is very useful the reading of: MELLA (1997).
} 
scientific research method ${ }^{6}$ developed in the Social Sciences, uses the architecture of the classic scientific model - object, theory, method.

The new educational model sought to avoid the artificial separation between some technical issues - traditionally identified with archives or libraries - that characterized previous LIS education and training in Portugal. Procedures related to the organization and representation of information such as description, cataloguing and indexing, which in Portuguese programmes had been assigned to different courses, depending on whether the training was directed to archivists or librarians, are integrated in the same courses in the new model and include museums standards as well, as part of information description and representation (Ribeiro, 2007).

This unified approach still aims to perform a synthesis with Information Systems (technological systems devoted to the storage and retrieval of information) that are increasingly being implemented inside organizations in general. In this way, technology becomes embedded in information procedures and actions, as is obvious in the digital era we live in.

The educational model brings together within the scope of the main academic area - Information Science - a set of courses that, on one side, ensures a theoretical and methodological unity and, on the other side, includes the applied components of this field, with their specializations. Theory and research methods in IS, systems analysis, information organization and representation, technical and standard procedures related to storage and retrieval, information management, along with informational behaviour and seeking, information ethics or information preservation constitute, naturally, the core curriculum. These main subjects are complemented by a set of other subjects devoted to the applied components of Information Science, as they are related to the context where information is created, managed, retrieved and used (archives, libraries, museums or technological information systems), in a transdisciplinary relationship.

The curriculum is also completed by several topics (some mandatory and some optional) that represent the interdisciplinary relationships with other academic areas (Linguistics, Logics, Management, Computer Science, History, Law, etc.).

To better illustrate this transdisciplinary dimension and, at the same time, the interdisciplinary relationships, see Fig. 1.

This education model was implemented at undergraduate level (bachelor) in the University of Porto in 2001 as a partnership between its Faculty of Arts and Humanities and its Faculty of Engineering. It is oriented to educate information professionals able to work in any organisational context. From the beginning, it tried to follow, in what concerns professional profiles and competences, the Euroguide LIS: a guide to competencies for European professionals in library and information services, by the European Council of Information Associations (European, 2004).

Before the Bologna reform, this bachelor's degree (with a 4 years curriculum) included six months of practicum in a work context, either in the private or the public

\footnotetext{
${ }^{6}$ See: De Bruyne (1974); Lessard-Hébert (1994).
} 


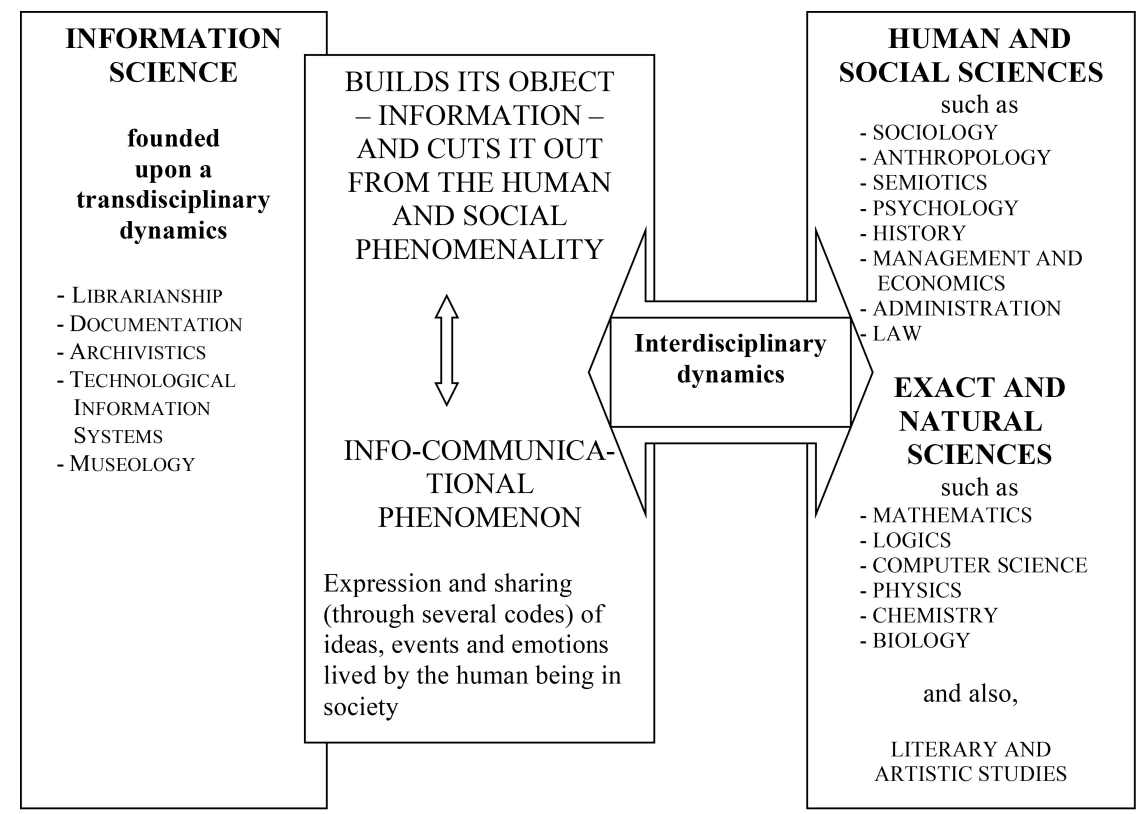

Fig. 1. Diagram of the trans and interdisciplinary construction of Information Science (adapted from Silva, 2006, p. 28).

sector and within a diversity of services, with a clear domain of sectors related to organizational information management, independently of the existence inside the organization of an archives or a library service. Thus, about $60 \%$ of the students found their first job in private companies, which shows that they are able to work in any organizational context where an information manager is needed.

The University of Porto's model began slowly inspiring other schools to create similar undergraduate programmes, although they did not always adopt the name "Information Science" (Cadernos, 2006). This influence grew after 2007, driven by the Bologna Process, because the previous education model (CECD) did not deliver an academic degree, thus, universities started abandoning it. If we look at the changes that occurred in the last twelve years, after Bologna, we see a clear domain of the $1^{\text {st }}$ cycle (bachelor degree) and $2^{\text {nd }}$ cycle (master's level) in the higher education public institutions (mainly universities) and the progressive disappearance of postgraduate programmes, namely the CECD.

The $1^{\text {st }}$ cycle can be taken by anyone who completes secondary school and the degree is obtained with success in, at least, 180 ECTS (European Credit Transfer and Accumulation System). Usually the programmes have a duration of six semesters (three years).

Slowly, there was a general and consensual understanding that high level education in LIS should go from bachelor to $\mathrm{PhD}$ level, like in almost every other academic fields. 
Portugal is currently witnessing a period of change which encourages an effective reflection and curricula benchmarking without forgetting either the outcomes that the ongoing research will deliver or the required adjustment of an education model that should also be directed to the acquisition of competences truly adapted to the market and research needs in the information era.

\section{Current institutional context of IS education}

\subsection{Undergraduate and postgraduate education and the accreditation process}

Currently, the Portuguese higher education system is organized in a binary structure that integrates university education and polytechnic education and is taught in public and private institutions.

University education is focused in the promotion of research and creation of knowledge, aiming to ensure a strong scientific and cultural training while providing technical instruction targeted to professional and cultural activities. On the other hand, Polytechnic education is focused on applied research and development perspective aimed at understanding and solving concrete problems while also providing a solid cultural and technical training at the academic level (Portugal, 2019).

Both new study programmes and programmes already in operation require assessment and accreditation by the Portuguese Agency for Assessment and Accreditation of Higher Education (A3ES). This Agency was created by Decree-Law n. 369/2007 (Portugal, 2007) and is a full member of the European Association for Quality Assurance in Higher Education, as well as recorded in the European Quality Assurance Register. The main objective of A3ES is to promote the improvement of the performance of higher education institutions and their study programmes, acting through the identification of the accreditation criteria and procedures to be followed by all higher education system institutions - University and Polytechnic education, public and private sector - and definition of the consequences of assessment for the operation of study programmes and institutions (Portugal, 2013a).

The evaluation for accreditation occurs every six years and the process includes a self-assessment report, prepared by the entity to be assessed which must correspond to a critical analysis of the programme according to a questionnaire provided by the agency.

Assessment criteria take into account the following:

“a) Objectives of the study programme;

b) Internal organisation and quality assurance mechanisms;

c) Material resources and partnerships;

d) Qualification and allocation of the academic and non-academic staffs;

e) Characterization of the students;

f) Teaching and learning environment;

g) Teaching objectives, curricular structure and syllabus; 
h) Organization of the curricular units;

i) Teaching and learning methodologies;

j) Results of academic, scientific, technological and artistic and other activities;

k) Proposals for performance improvement actions" (Portugal, 2013b).

An external assessment committee, composed by independent experts, analyses the self-assessment report and visits the higher education institution in order to meet representatives of the bodies of the institution, students and graduates, faculty members and non-teaching staff, and also employers in the area of the study programme to be assessed. Then a preliminary report is drafted by the external assesssment committee, which may be subject to comment by the institution. A final report is created consisting in information about the assessment decision and, eventually, recommendations to be followed. Taking into account the final report of the external assessment committee, the A3ES Management Board takes the final decision on accreditation (Portugal, 2013a).

\subsection{Current programmes and their organizational framework}

The requirements of accreditation/assessment procedures had a deep impact in the Portuguese IS educational offerings in all study cycles. In fact, a severe reduction of the available programmes took place in recent years, resulting in a high quality level of the remaining programmes. Nevertheless, accreditation may be considered for a period of 6 years without conditions or for a shorter period with certain conditions to be followed by the higher education institution, after which the assessment is reviewed.

In order to collect data related to existing programmes in the 2018/19 academic year, the results of the accreditation process of IS study programmes were consulted online in the database available at A3ES' website. ${ }^{7}$ Data were collected considering the International Standard Classification of Education (ISCED), code 322 - Library, information, archive. As a result, we collected data for eleven programmes which are presented below in Table 1, ordered by level of study cycle and then by higher education (HE) institution.

IS education in Portugal is dominated by public institutions and by university programmes. The eleven programmes offered in the 2018/19 academic year include three Bachelors, six Masters and two $\mathrm{PhD}$. There are only two programmes, a Bachelor and a Master, offered by a Polytechnic institution. In addition, the educational offerings are concentrated in institutions with a tradition in this area. Indeed, the University of Coimbra and the University of Porto are the only ones that offer IS education at the three academic levels (Bachelor, Master and $\mathrm{PhD}$ ).

Regardless of being classified with the ISCED code 322, Portuguese IS educational can be considered somehow heterogeneous, if we consider the programmes

\footnotetext{
${ }^{7}$ Available at: https://www.a3es.pt/en/accreditation-and-audit/accreditation-process-results (access 2019-04-29).
} 
Table 1

IS education programmes in the 2018/19 academic year

\begin{tabular}{|c|c|c|c|c|}
\hline $\begin{array}{l}\text { Denomination of } \\
\text { the programme }\end{array}$ & HE institution & Modality & $\begin{array}{l}\text { Number of } \\
\text { accreditation } \\
\text { years }\end{array}$ & $\begin{array}{c}\text { Year of } \\
\text { accreditation }\end{array}$ \\
\hline $\begin{array}{l}\text { Bachelor in Documentation } \\
\text { and Information Sciences and } \\
\text { Technologies }\end{array}$ & $\begin{array}{l}\text { Polytechnic Institute } \\
\text { of Porto }\end{array}$ & Classroom based & 6 & 2014 \\
\hline $\begin{array}{l}\text { Bachelor in Information } \\
\text { Science }\end{array}$ & University of Coimbra & Classroom based & 6 & 2015 \\
\hline $\begin{array}{l}\text { Bachelor in Information } \\
\text { Science }\end{array}$ & University of Porto & Classroom based & 6 & 2015 \\
\hline $\begin{array}{l}\text { Master in Information } \\
\text { Management and Curation }\end{array}$ & $\begin{array}{l}\text { Nova University of } \\
\text { Lisbon }\end{array}$ & Classroom based & 3 & 2016 \\
\hline $\begin{array}{l}\text { Master in Business } \\
\text { Information }\end{array}$ & $\begin{array}{l}\text { Polytechnic Institute } \\
\text { of Porto }\end{array}$ & Classroom based & 2 & 2018 \\
\hline $\begin{array}{l}\text { Master in Information } \\
\text { Management and School } \\
\text { Libraries }\end{array}$ & Open University & E-learning & 3 & 2016 \\
\hline $\begin{array}{l}\text { Master in Information } \\
\text { Science }\end{array}$ & University of Coimbra & $\begin{array}{l}\text { Mixed classroom } \\
\text { and b-learning }\end{array}$ & 6 & 2013 \\
\hline $\begin{array}{l}\text { Master in Documentation and } \\
\text { Information Sciences }\end{array}$ & University of Lisbon & Classroom based & 6 & 2015 \\
\hline $\begin{array}{l}\text { Master in Information } \\
\text { Science }\end{array}$ & University of Porto & Classroom based & 6 & 2015 \\
\hline $\mathrm{PhD}$ in Information Science & University of Coimbra & Classroom based & 6 & 2015 \\
\hline $\begin{array}{l}\text { PhD in Information and } \\
\text { Communication in Digital } \\
\text { Platforms }\end{array}$ & $\begin{array}{l}\text { University of Porto }+ \\
\text { University of Aveiro }\end{array}$ & $\begin{array}{l}\text { Mixed classroom } \\
\text { and b-learning }\end{array}$ & 6 & 2014 \\
\hline
\end{tabular}

designations. In fact, a consultation of the study plans and courses syllabi clearly showed that they express different approaches of IS education.

The programmes offered at the Polytechnic are more focused on professional and practical education, while unsurprisingly, Universities' programmes include a strong scientific background.

University of Coimbra offers a bachelor in IS which can be exclusively dedicated to this scientific area or may include a specific group of mandatory curricular units combined with a minor in one of the other programmes offered by the Faculty of Arts and Humanities. Moreover, the University of Porto shows, both in its Bachelor and Master degrees, an integrated approach to IS, which means that archives, libraries, documentation centres, museums and other information services are approached together and not differentiated as far as information phenomenon is concerned. At the University of Porto, the programmes are taught jointly by the Faculty of Arts and Humanities and by the Faculty of Engineering, as stated previously. This partnership allows a strong and consolidated education on humanistic/social sciences but also with technological contents.

The University of Lisbon, on the other hand, maintains the "documentation science" point of view, that highlights the theoretical background of the Master in some way still following the previous specialization programme (CECD) already closed. 
Three Master programmes have specific approaches, targeting business information, curation, and school libraries.

In terms of the doctoral programmes available, the University of Coimbra offers a recent one exclusively devoted to IS while the University of Porto, together with the University of Aveiro, promote a quite different approach within the Communication and Information Sciences, in line with some foreign schools, mostly American ones. University of Porto is a member of the world network of iSchools ${ }^{8}$ in which we can find similar models integrating Information, Communication and Technology, but the Portuguese PhD programme in Information and Communication in Digital Platforms has been more influenced by the French model of an interdiscipline embedding Information and Communication Sciences (Sciences de l'Information et Communication (SIC). ${ }^{9}$

A common feature of IS education is related to the programmes' teaching modalities. Most programmes are classroom based, requiring face-to-face classes from students. Portuguese high education system is mostly based in classroom education practices, but there are experiences that may be applied in other institutions in the near future. As an example, a Master's programme at the University of Coimbra offers both classroom courses and blended learning courses.

The Open University is the single public distance education higher education institution in Portugal and since 2008 all its programs are taught in e-learning modality.

The years of accreditation of all programmes show that soon, there will be a new assessment period which may eventually bring some changes to the current IS educational scenario. Some differentiation between the programmes noted above may be justified by the organizational framework of the IS education.

As described in Table 2, the programmes' organization and their integration in organic units and/or departments are not the same in the several institutions.

At the Nova University of Lisbon, the Master in Information Management and Curation is housed within the Department of History of the School of Social Sciences and Humanities and taught jointly with the Information Management School. The Polytechnic Institute of Porto integrates a Higher Institute of Accounting and Administration where the Bachelor in Documentation and Information Sciences and Technologies and the Master in Business Information are housed. The Master in Information Management and School Libraries from the Open University is included in the offer of the Department of Education and Distance Learning. Other programmes from the Universities of Coimbra, Lisbon and Porto, are housed within the respective Faculties of Arts and Humanities, although within diverse departments and organic units.

In the University of Coimbra, all the study cycles are taught by faculty members of the Department of Philosophy, Communication and Information, where the Information Section is located.

\footnotetext{
${ }^{8}$ See: https://ischoolsinc.wildapricot.org/ (access 2019-05-02).

${ }^{9}$ For further reading on this topic, see: Ribeiro and Silva (2018).
} 
Table 2

Organizational framework of IS education programmes

\begin{tabular}{|c|c|c|}
\hline HE institution & Organic unit/school & Department/section \\
\hline Nova University of & School of Social Sciences and Humanities & Department of History \\
\hline Lisbon & Information Management School & \\
\hline Open University & Department of Education and Distance & \\
\hline & Learning & \\
\hline Polytechnic Institute & Higher Institute of Accounting and & \\
\hline of Porto & Administration of Porto & \\
\hline University of Aveiro & Department of Communication and Art & \\
\hline University of Coimbra & Faculty of Arts and Humanities & Department of Philosophy, \\
\hline & & Communication and Information \\
\hline University of Lisbon & Faculty of Arts and Humanities & $\begin{array}{l}\text { Program in Documentation and } \\
\text { Information Sciences }\end{array}$ \\
\hline \multirow[t]{2}{*}{ University of Porto } & Faculty of Arts and Humanities & $\begin{array}{l}\text { Department of Communication } \\
\text { and Information Sciences }\end{array}$ \\
\hline & Faculty of Engineering & Department of Informatics \\
\hline
\end{tabular}

At the University of Lisbon, the Master's programme is not offered by any department, but it belongs to a "section" named Programme in Documentation and Information Sciences.

In the University of Porto's organizational framework, some substantial differences contribute to the particular specificities of its educational offer already mentioned. In the Bachelor and Master degrees in Information Science, taught jointly by the Faculty of Arts and Humanities and the Faculty of Engineering, the academic staff comes from different departments, mainly the Department of Communication and Information Sciences and the Department of Informatics. In addition, the $\mathrm{PhD}$ programme is taught jointly with another university (University of Aveiro). Thus, this $\mathrm{PhD}$ programme benefits from the collaboration of teaching staff from the Department of Communication and Art of the University of Aveiro, and faculty members of the Department of Communication and Information Sciences of the Faculty of Arts and Humanities of the University of Porto.

\section{Some final remarks}

More than 130 years of formal training, integrated in high education institutions, puts Portugal in a quite unique position when we compare its educational framework with other countries, either in Europe or in America, where academic education began later during the $20^{\text {th }}$ century. This long tradition enables us to reflect on the current situation of IS field in Portugal and to look at other countries where the establishment of IS programmes is much more recent although the development of the field in what concerns research and literature production is surprisingly more intense and advanced. Why is this?

In fact, the great number of programmes that existed until ten years ago were not characterized by quality, scientific development and research progress despite 
their academic framework, because the teaching staff was almost all non-academic people. The several programmes worked for years with professionals (librarians and archivists) teaching in part-time along with their job in a library, an archive or a documentation service. This means that research did not develop at the same time as teaching and, because of that, teaching was focused mainly on technicalities instead of on theory and methodology as the indispensable scientific background. Even today, in the Portuguese universities that have full-time staff devoted exclusively to teaching and research, all the faculty members were recruited from a professional context, as they previously worked as librarians, archivists or documentalists, with basic education in areas other than IS.

This set of circumstances explain why IS as a scientific field is still incipient in Portugal and, consequently, why so few Portuguese authors are represented in scientific databases of articles and citations. The new generations of IS bachelor, master and above all $\mathrm{PhD}$ graduates will certainly make a difference in the next decade, as it is expected that universities increase their academic staff according to accreditation processes and requirements.

\section{References}

Cadernos BAD (2006). 1

De Bruyne, P., Herman, J., \& De Schoutheete, M. (1974). Dynamique de la recherche en sciences sociales de pôles de la pratique méthodologique. Paris: PUF.

European Council of Information Associations (2004). Euroguide LIS. Vol. 1 - Competencies and aptitudes for European information professionals. $2^{\text {nd }}$ entirely rev. ed. [S. 1.]: ADBS Éditions.

Lessard-Hébert, M., Goyette, G., \& Boutin, G. (1994). Investigação qualitativa: fundamentos e práticas. Lisboa: Instituto Piaget.

Mella, P. (1997). Dai Sistemi al pensiero sistemico: per capire i sistemi e pensare con i sistemi. Milano: Franco Angeli.

Pinto, M.M.G.A. (2008). A Formação em informação e documentação: Portugal na contemporaneidade. In Formación, Investigación y Mercado Laboral en Información y Documentación en España y Portugal = Formação, Investigação e Mercado de Trabalho em Informação e Documentação em Espanha e Portugal. Ed. José António Frías, Críspulo Travieso. Salamanca: Universidad, pp. 91-142.

Portugal. Agência de Avaliação e Acreditação do Ensino Superior (2013a). Assessment Handbook. Version 1.1. Available at: https://www.a3es.pt/sites/default/files/Assessment\%20Handbook_Final.pdf (access 2019-04-29).

Portugal. Agência de Avaliação e Acreditação do Ensino Superior (2013b). Regulation n. 392/2013: Regimen for the assessment and accreditation procedures of higher education institutions and their study programmes. Available at: https://www.a3es.pt/en/accreditation-and-audit/normative-framework/ regulations-assessment-and-accreditation-procedures (access 2019-04-29).

Portugal. Direção Geral do Ensino Superior (2019). Portuguese Higher Education System. Available at: https://www.dges.gov.pt/en/pagina/portuguese-higher-education-system (access 2019-04-29).

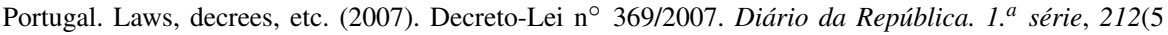
Nov.), 8.032-8.040.

Ribeiro, F. (2008). LIS Education in Portugal between academia and practice. Education for Information, 26(Mar.), 33-42.

Ribeiro, F. (2007). An Integrated perspective for professional education in Libraries, Archives and Museums: A new paradigm, a new training model. Journal of Education for Library and Information Science, 48(2) (Spring), 116-124. 
Ribeiro, F., \& Silva, A.M. (2018). The Interdisciplinary field of Information and Communication: a preliminary study on the current structure of iSchools. In Colloque ISKO France 2017, 11 e, Paris, 2017. Fondements épistémologiques et théoriques de la Science de l'Information-Documentation: actes... Coord. Widad Mustafa El Hadi. London: ISTE Éditions, 403-411.

Ribeiro, F., \& Silva, A.M. (2012). Documentation/Information and their paradigms: characterization and importance in research, education, and professional practice. Knowledge Organization: International Journal Devoted to Concept, Theory, Classification, Indexing and Knowledge Representation, 39(2), 111-124.

Silva, A.M. (2006). A Informação: da compreensão do fenómeno e construção do objecto científico. Porto: Edições Afrontamento; CETAC.COM.

Silva, A.M., \& Ribeiro, F. (2002). Das "ciências" documentais à ciência da informação: ensaio epistemológico para um novo modelo curricular. Porto: Edições Afrontamento. 